\title{
Hyperbaric oxygen on rehabilitation of brain tumors after surgery and effects on TNF- $\alpha$ and IL-6 levels
}

\author{
SHICAI HOU ${ }^{1}$, GUIMEI WU ${ }^{2}$, JINGJING LIANG $^{3}, \mathrm{HUANCHUN} \mathrm{CHENG}^{4}$ and $\mathrm{CHAO} \mathrm{CHEN}^{2}$ \\ Departments of ${ }^{1}$ Rehabilitation, ${ }^{2}$ Neurosurgery (Ward 1) and ${ }^{3}$ Pediatrics (III), People's Hospital of Rizhao, Rizhao, \\ Shandong 276800; ${ }^{4}$ Department of Surgery, Xujiahu Health Center, Linyi, Shandong 276400, P.R. China
}

Received May 17, 2018; Accepted January 21, 2019

DOI: $10.3892 / \mathrm{ol} .2019 .10000$

\begin{abstract}
Hyperbaric oxygenation (HBO) on postoperative rehabilitation of brain tumors and effects on tumor necrosis factor- $\alpha$ (TNF- $\alpha$ ) and interleukin-6 (IL-6) levels were explored. A retrospective analysis of 132 patients with brain tumors treated in the People's Hospital of Rizhao from October 2014 to October 2017 was performed. There were 62 patients in the observation group and 70 patients in the control group. Patients in the control group were treated with conventional drugs, and patients in the observation group were treated with $\mathrm{HBO}$ on the basis of conventional drug therapy. Levels of serum TNF- $\alpha$ and IL- 6 were measured by ELISA before and after treatment. Cerebral arterial flow velocity and spasticity were measured by cranial color Doppler ultrasonography. Neurological function deficit (NFD) and activities of daily living (ADL) were used to evaluate the clinical recovery of the patients. Clinical efficacy was compared and analyzed. There were no significant differences between the two groups before treatment $(\mathrm{P}>0.05)$. After treatment, serum TNF- $\alpha$ and IL-6 levels were significantly lower than pretreatment levels $(\mathrm{P}<0.05)$, and serum TNF- $\alpha$ and IL- 6 levels in the observation group were lower than those in the control group $(\mathrm{P}<0.05)$. Cerebral arterial flow velocity in observation group after treatment was significantly lower than that in the control group. The number of patients with cerebral arterial spasm after treatment in the observation group was significantly smaller than that in the control group. NFD scores in the observation group were lower than those in the control group after treatment. After treatment, ADL scores in the observation group were significantly higher than those in the control group $(\mathrm{P}<0.05)$. The comprehensive treatment effect of HBO is significant. It can inhibit the expression of inflammatory factors in serum and reduce cerebral arterial flow velocity and effectively reduce the number of patients with cerebral arterial spasm. It can reduce NFD and improve
\end{abstract}

Correspondence to: Dr Chao Chen, Department of Neurosurgery (Ward 1), People's Hospital of Rizhao, 126 Taian Road, Rizhao, Shandong 276800, P.R. China

E-mail: ey27b5@163.com

Key words: brain tumor, HBO, TNF- $\alpha$, IL-6, rehabilitation effect the quality of life of patients. Therefore, it is worthy of clinical popularization.

\section{Introduction}

Brain tumors are generally divided into two major categories, primary tumors originating from intracranial tissue and metastatic tumors originating from other parts (1). Prevalence of metastatic brain tumors is 10 -fold that of primary brain tumors, and brain metastases occur in $20-40 \%$ of tumor patients $(2,3)$. Brain tumors seriously endanger human life and health. Brain tumors mostly occur in young adults and gliomas is the most common type (4). Genetic factors, radiation exposure, intracranial injury, and viral factors are correlated with the etiology of brain tumors (5). Due to the high metabolic state of tumors and the abnormal disorder of blood vessels, oxygen level required by tumor cells is significantly higher than oxygen supply, which in turn causes hypoxia of the tumor tissues. It has been reported that the existence of the hypoxic microenvironment may cause the recurrence of tumors and increase the degree of malignancy $(6,7)$.

Hyperbaric oxygen (HBO) is an adjuvant therapy that plays an important role in the treatment of malignant tumors (8). $\mathrm{HBO}$ is pure oxygen with a higher pressure than normal atmospheric pressure, and its mechanism of action mainly depends on increasing the oxygen capacity in cytoplasm and further increasing oxygen content in cells, resulting in a decrease in cerebrovascular blood flow due to cerebral vasoconstriction, and a corresponding decrease in intracranial pressure (9). Inflammatory factors can cause tissue damage after brain injury by causing excessive release of inflammatory mediators, and HBO can improve brain metabolism and restore brain function (10). In the development of brain tumors, tumor necrosis factor- $\alpha$ (TNF- $\alpha$ ) and interleukin- 6 (IL-6) are polypeptide cytokines involved in inflammation and have a wide range of biological activities (11). Elevated levels of IL- 6 and TNF- $\alpha$ in serum can cause the body to undergo a stress reaction after brain injury in order to destroy the blood-brain barrier, and cause monocytes and neutrophils to enter the brain (12).

The current study aimed to investigate the effect of HBO on postoperative rehabilitation of brain tumors and the effects on TNF- $\alpha$ and IL- 6 in patients, so as to provide references for the treatment of brain tumors. 


\section{Patients and methods}

General information. This is a retrospective study. A total of 132 brain tumor patients who were admitted to the People's Hospital of Rizhao (Rizhao, China) from October 2014 to October 2017 were selected. Those patients included 64 males and 68 females, with an age range of 13-72 years. There were 62 patients in the observation group and 70 patients in the control group. Patients in the control group were treated with conventional drugs, and patients in the observation group were treated with $\mathrm{HBO}$ on the basis of conventional drug therapy. There was no statistically significant difference in general data between the groups $(\mathrm{P}>0.05)$. All the cases were diagnosed by imaging and postoperative pathological examinations. The patients were excluded from pregnancy, lactation, bleeding after brain surgery and contraindications, tumors in other parts of the body, cerebral thrombosis, liver and kidney dysfunction, and other diseases. The study was approved by the Ethics Committee of People's Hospital of Rizhao. All patients or their family members signed informed consent. General information is shown in Table I.

Reagents and equipment. TNF- $\alpha$ and IL-6 ELISA kits were purchased from Wuhan Boster Biological Technology, Ltd., Wuhan, China. The Anthus PHOMO automatic microplate reader was purchased from Shanghai Zhongsheng Science Development Co., Ltd. (Beijing, China). The KJ-2V4M Ultrasonic Transcranial Doppler Blood Flow Analyzer was purchased from Nanjing Kejin Industrial Co., Ltd. (Nanjing, China). Medical air pressurized cabin was purchased from Guizhou Fenglei Oxygen Capsules Co., Ltd. Vitamin C was purchased from Guangdong Hengjian Pharmaceutical Co., Ltd., Jiangmen, China (state approval no. H44021171).

Two treatment methods. In the control group, routine treatment methods such as brain neurotrophic drugs, dehydration drugs, hemostatic drugs, and awakening agents were used, and the observation group was supplemented with HBO treatment. Medical air pressurized cabin was used with treatment pressure $0.18 \mathrm{Mpa}$. Pressure was increased for $25 \mathrm{~min}$ and patients were asked to wear mask to absorb pure oxygen for $60 \mathrm{~min}$, rest for $10 \mathrm{~min}$ and decompression for $25 \mathrm{~min}$, once a day. Routine use of vitamin C (0.1 g/time, 3 times per day) was performed during BO treatment. Treatment efficacy was reviewed after $10 \mathrm{HBO}$ treatments.

Detection of serum TNF- $\alpha$ and IL-6. Peripheral venous blood ( $3 \mathrm{ml}$ ) was extracted from each patient at 1 day before treatment and 1 day after treatment. Blood was centrifuged at 2,300 x g for $8 \mathrm{~min}$ to collect serum. Serum TNF- $\alpha$ and IL- 6 levels were measured by ELISA according to the instructions of the kit.

Observation indicators. Cerebral arterial flow velocity and spasticity were measured by cranial color Doppler ultrasonography. Neurological function deficit (NFD) and activities of daily living (ADL) were used to evaluate the clinical recovery of the patients. Clinical efficacy was compared and analyzed.

Statistical analysis. SPSS 17.0 statistical software was used for analysis (Shanghai Cabit Information Technology Co., Ltd., Shanghai, China). Chi-square test was used for the comparisons
Table I. General information.

\begin{tabular}{|c|c|c|c|c|}
\hline Indexes & $\begin{array}{l}\text { Observation } \\
\qquad(n=62)\end{array}$ & $\begin{array}{l}\text { Control } \\
(\mathrm{n}=70)\end{array}$ & $\chi^{2} / \mathrm{t}$ & P-value \\
\hline \multicolumn{5}{|l|}{ Age (years) } \\
\hline$\geq 43$ & $29(46.77)$ & $35(50.00)$ & 0.137 & 0.730 \\
\hline$<43$ & $33(53.23)$ & $35(50.00)$ & & \\
\hline \multicolumn{5}{|l|}{ Sex } \\
\hline Male & $35(56.45)$ & $29(41.43)$ & 2.971 & 0.116 \\
\hline Female & $27(43.55)$ & $41(58.57)$ & & \\
\hline \multicolumn{5}{|l|}{$\begin{array}{l}\text { Course of } \\
\text { disease (years) }\end{array}$} \\
\hline$\geq 2$ & $16(25.81)$ & $20(28.57)$ & 0.127 & 0.845 \\
\hline$<2$ & $46(74.19)$ & $50(71.43)$ & & \\
\hline $\begin{array}{l}\text { Blood glucose } \\
(\mathrm{mmol} / \mathrm{l})\end{array}$ & $5.64 \pm 2.13$ & $5.82 \pm 2.09$ & 0.489 & 0.625 \\
\hline Hemoglobin (g/l) & $12.24 \pm 1.25$ & $12.32 \pm 1.07$ & 0.396 & 0.693 \\
\hline $\begin{array}{l}\text { Blood calcium } \\
(\mathrm{mmol} / \mathrm{l})\end{array}$ & $2.33 \pm 0.25$ & $2.28 \pm 0.31$ & 1.012 & 0.314 \\
\hline Hematocrit (\%) & $37.25 \pm 5.24$ & $37.92 \pm 5.13$ & 0.741 & 0.460 \\
\hline Albumin (g/l) & $39.86 \pm 3.56$ & $40.18 \pm 4.21$ & 0.468 & 0.640 \\
\hline $\begin{array}{l}\text { Insulin-like growth } \\
\text { factor-I }(\mathrm{ng} / \mathrm{ml})\end{array}$ & $232.53 \pm 19.28$ & $235.46 \pm 18.86$ & 0.882 & 0.380 \\
\hline Sialic acid (mg/l) & $252.26 \pm 46.84$ & $254.31 \pm 45.67$ & 0.254 & 0.800 \\
\hline
\end{tabular}

of countable data, Student's t-test was used for comparison of measurement data, and paired t-test was used for comparison before and after treatment in the same group. $\mathrm{P}<0.05$ was considered to indicate a statistically significant difference.

\section{Result}

Serum TNF- $\alpha$ and IL-6 levels in the two groups before and after treatment. Levels of TNF- $\alpha$ and IL- 6 in the observation group were not significantly different from those in the control group before treatment $(\mathrm{P}>0.05)$. Levels of TNF- $\alpha$ and IL-6 in both groups were significantly reduced after treatment $(\mathrm{P}<0.001)$. After treatment, levels of TNF- $\alpha$ and IL-6 were significantly lower in the observation group than in the control group $(\mathrm{P}<0.001)$ (Fig. 1; Table II).

Comparison of flow velocity of middle cerebral artery by transcranial Doppler before and after treatment in two groups of patients. There was no significant difference in the flow rate of cerebral arteries between the observation and the control groups before treatment $(\mathrm{P}>0.05)$. Flow rate of cerebral arteries in both groups were significantly reduced after treatment $(\mathrm{P}<0.001)$. Cerebral arterial flow velocity in the observation group after treatment of $96.74 \pm 20.86 \mathrm{~cm} / \mathrm{sec}$ was significantly lower than that in the control group $119.52 \pm 18.27 \mathrm{~cm} / \mathrm{sec}(\mathrm{P}<0.001)$ (Fig. 2; Table III).

Comparison of cerebral arterial spasm between the two groups before and after treatment. Before treatment, there was no significant difference in the incidence of arterial spasm between the observation and the control groups $(\mathrm{P}>0.05)$. 

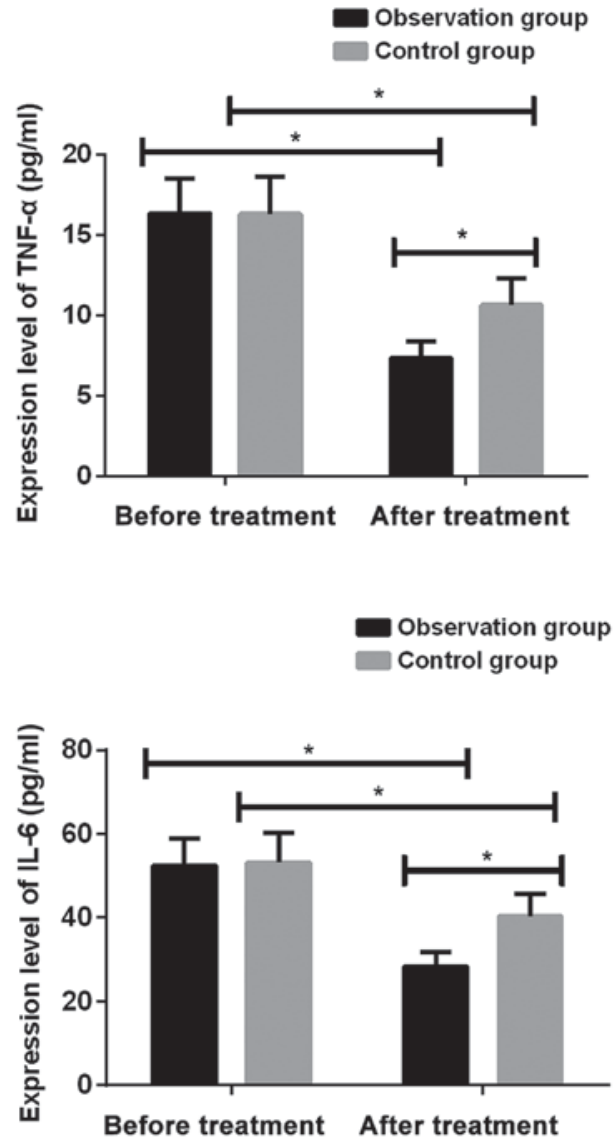

Figure 1. Levels of serum TNF- $\alpha$ and IL- 6 before and after treatment in both groups. ELISA results showed that levels of TNF- $\alpha$ and IL-6 in the observation group were not significantly different than those in the control group before treatment $(\mathrm{P}>0.05)$. Levels of TNF- $\alpha$ and IL-6 in both groups were significantly reduced after treatment $(\mathrm{P}<0.001)$. After treatment, levels of TNF- $\alpha$ and IL- 6 were significantly lower in the observation group than in the control group ("P<0.001). TNF- $\alpha$, tumor necrosis factor- $\alpha$; IL-6, interleukin-6.

Table II. Serum TNF- $\alpha$ and IL-6 levels in the groups before and after treatment.

\begin{tabular}{lcccc}
\hline Groups & Cases & $\begin{array}{c}\text { Treatment } \\
\text { time }\end{array}$ & $\begin{array}{c}\text { TNF- } \alpha \\
(\mathrm{pg} / \mathrm{ml})\end{array}$ & $\begin{array}{c}\text { IL-6 } \\
(\mathrm{pg} / \mathrm{ml})\end{array}$ \\
\hline Observation & \multirow{2}{*}{62} & Before & $16.35 \pm 2.15$ & $52.35 \pm 6.58$ \\
& & After & $7.35 \pm 1.04^{\mathrm{a}}$ & $28.35 \pm 3.42^{\mathrm{a}}$ \\
& & t value & 29.67 & 25.48 \\
Control & \multirow{2}{*}{70} & P-value & $<0.001$ & $<0.001$ \\
& & Before & $16.32 \pm 2.28$ & $53.08 \pm 7.12$ \\
& & After & $10.65 \pm 1.64$ & $40.27 \pm 5.46$ \\
& & t value & 16.89 & 11.94 \\
& & P-value & $<0.001$ & $<0.001$ \\
\hline
\end{tabular}

${ }^{\mathrm{a}} \mathrm{P}<0.001$, compared with post-treatment level in the control group. TNF- $\alpha$, tumor necrosis factor- $\alpha$; IL- 6 , interleukin- 6 .

Incidence of arterial spasm was significantly decreased after treatment in both groups $(\mathrm{P}<0.001)$. After treatment, there were 9 patients with cerebral arterial spasm in the observation group and 27 patients with cerebral arterial spasm in the

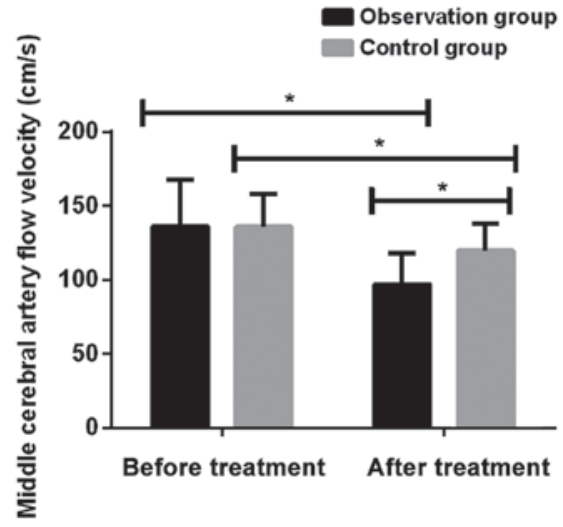

Figure 2. Comparison of cerebral arterial flow velocity before and after treatment in the two groups of patients. There was no significant difference in cerebral arterial flow velocity between the observation group and the control group before treatment $(\mathrm{P}>0.05)$. Cerebral arterial flow velocity in both groups were significantly reduced after treatment $(\mathrm{P}<0.001)$. Cerebral arterial flow velocity in the observation group after treatment was significantly lower than that in the control group ( $\mathrm{P}<0.001)$.

Table III. Comparison of cerebral arterial flow velocity in the two groups before and after treatment.

\begin{tabular}{|c|c|c|c|c|c|}
\hline Groups & Cases & $\begin{array}{l}\text { Treatment } \\
\text { time }\end{array}$ & $\begin{array}{l}\text { Cerebral arterial } \\
\text { flow velocity } \\
(\mathrm{cm} / \mathrm{sec})\end{array}$ & $\mathrm{t}$ value & P-value \\
\hline Observation & 62 & $\begin{array}{l}\text { Before } \\
\text { After }\end{array}$ & $\begin{array}{c}135.89 \pm 31.42 \\
96.74 \pm 20.86^{\mathrm{a}}\end{array}$ & 8.174 & $<0.001$ \\
\hline Control & 70 & $\begin{array}{l}\text { Before } \\
\text { After }\end{array}$ & $\begin{array}{l}135.78 \pm 21.84 \\
119.52 \pm 18.27\end{array}$ & 4.778 & $<0.001$ \\
\hline
\end{tabular}

${ }^{\text {a }}<<0.001$, compared with post-treatment level in the control group.

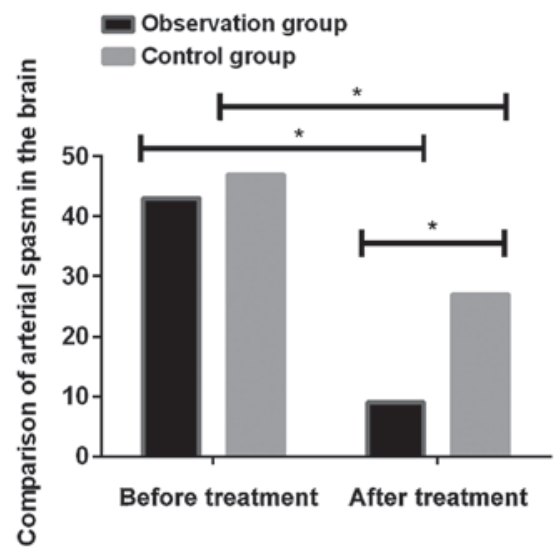

Figure 3. Comparison of cerebral arterial spasm between the two groups before and after treatment. Before treatment, there was no significant difference in incidence of arterial spasm between the observation group and the control group $(P>0.05)$. Incidence of arterial spasm was significantly decreased after treatment in both groups $(\mathrm{P}<0.001)$. After treatment, number of patients with cerebral arterial spasm was significantly smaller in the observation group than in the control group $($ ( $\mathrm{P}<0.001)$.

control group. Significant differences were found between the two groups $(\mathrm{P}<0.05)$ (Fig. 3; Table IV). 
Table IV. Comparison of cerebral arterial spasm between the two groups before and after treatment.

\begin{tabular}{lclccc}
\hline Groups & Cases & $\begin{array}{c}\text { Treatment } \\
\text { time }\end{array}$ & $\begin{array}{c}\text { Cerebral arterial } \\
\text { spasm, n (\%) }\end{array}$ & $\chi^{2}$ & P-value \\
\hline Observation & 62 & Before & $43(69.35)$ & 38.29 & $<0.001$ \\
& & After & $9(14.52)^{\mathrm{a}}$ & & \\
Control & 70 & Before & $47(67.14)$ & 11.47 & $<0.001$ \\
& & After & $27(38.57)$ & & \\
\hline
\end{tabular}

${ }^{\text {a }}<0.001$, compared with post-treatment level in the control group.

A Observation group Control group
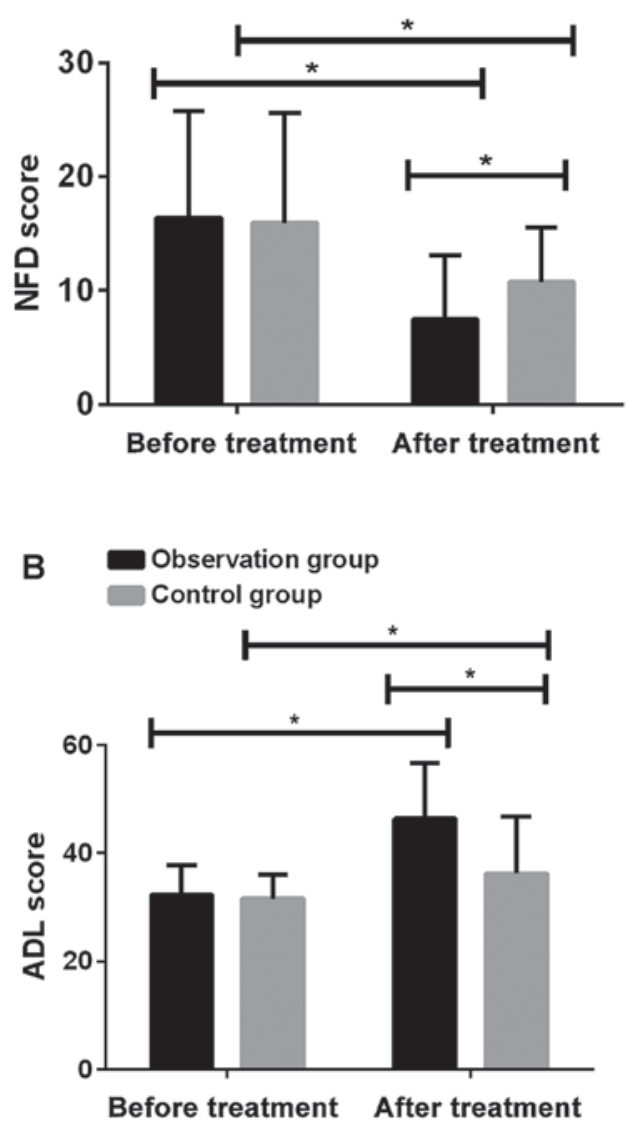

Figure 4. Comparison of NFD and ADL scores before and after treatment in two groups of patients. (A) Results showed that there was no significant difference in NFD scores between two groups before treatment $(P>0.05)$. NFD scores were significantly reduced after treatment $(P<0.0001)$. After treatment, NFD score was lower in the observation group than in the control group $(\mathrm{P}<0.001)$. (B) Results showed that there was no significant difference in ADL scores between two groups before treatment $(\mathrm{P}>0.05)$. ADL scores were significantly increased after treatment $(\mathrm{P}<0.0001)$. After treatment, ADL score was higher in the observation group than in the control group ("P<0.001). NFD, neurological function deficit; ADL, activities of daily living.

Comparison of NFD and ADL scores before and after treatment in two groups of patients. Before treatment, there was no significant difference in NFD and ADL scores between two groups $(P>0.05)$. After treatment, NFD scores were significantly reduced and ADL scores were significantly increased
Table V. Comparison of NFD and ADL scores before and after treatment in two groups of patients.

\begin{tabular}{lcccc}
\hline Groups & Cases & $\begin{array}{c}\text { Treatment } \\
\text { time }\end{array}$ & $\begin{array}{c}\text { NFD } \\
\text { score }\end{array}$ & $\begin{array}{c}\text { ADL } \\
\text { score }\end{array}$ \\
\hline Observation & \multirow{2}{*}{62} & Before & $16.35 \pm 9.38$ & $32.25 \pm 5.46$ \\
& & After & $7.52 \pm 5.57^{\mathrm{a}}$ & $46.38 \pm 10.27^{\mathrm{a}}$ \\
& & t value & 6.373 & 9.566 \\
& & P-value & $<0.001$ & $<0.001$ \\
Control & \multirow{2}{*}{70} & Before & $15.93 \pm 9.64$ & $31.56 \pm 4.39$ \\
& & After & $10.74 \pm 4.75$ & $36.28 \pm 10.51$ \\
& & t value & 4.041 & 3.467 \\
& & P-value & $<0.001$ & $<0.001$ \\
\hline
\end{tabular}

${ }^{a} \mathrm{P}<0.001$, compared with post-treatment level in the control group. NFD, neurological function deficit; ADL, activities of daily living.

$(\mathrm{P}<0.001)$. NFD score in the observation group after treatment (7.52 \pm 5.57$)$ was significantly lower than that in the control group $(10.74 \pm 4.75 ; \mathrm{P}<0.001)$ and ADL score in the observation group $(46.38 \pm 10.27)$ was significantly higher than that in the control group (36.28 $\pm 10.51 ; \mathrm{P}<0.001)$ (Fig. 4; Table V).

\section{Discussion}

Brain tumor is a common neurosurgical malignancy in clinical practice. Continuous growth of intracranial tumors will compress surrounding tissues, resulting in nerve compression and cerebral edema (13). Studies have shown that most patients with brain tumors have symptoms of intracranial hypertension (14). Surgical treatment is currently the preferred treatment for brain tumors in clinical practice, but it cause some trauma to nerve tissue while removing tumors (15). Brain function recovery is a long process (16). HBO has a significant effect on decompression sickness, hypoxic-ischemic encephalopathy, and anaerobic infections (17-19). HBO has the following characteristics: it is beneficial to improve tissue hypoxia; it has significant curative effect on decompression sickness and thrombosis; it can reduce tissue edema, and brain edema can be controlled; and it can inhibit the growth of some aerobic and anaerobic bacteria $(20,21)$.

Results of this study showed that levels of TNF- $\alpha$ and IL-6 in the observation group were significantly lower than those in the control group after treatment $(\mathrm{P}<0.001)$. Findings reported by Chen et al (22) are basically consistent with our results, suggesting that HBO therapy can improve the inflammatory response in patients with brain tumors. It has been reported that the course of brain tumors is related to the efficacy of HBO therapy. Early use of HBO has important implications for the reduction of inflammatory factors, improvement of hypoxic symptoms, recovery of nerve function and brain function (23). In this study, cerebral arterial flow velocity in the observation group after treatment $(96.74 \pm 20.86 \mathrm{~cm} / \mathrm{sec})$ was significantly lower than that in the control group $(119.52 \pm 18.27 \mathrm{~cm} / \mathrm{sec} ; \mathrm{P}<0.001)$. After treatment, there were 9 patients with arterial spasm in the observation group and 27 patients with arterial spasm in the control group. The difference was statistically significant $(\mathrm{P}<0.05)$. 
After treatment, NFD score in the observation group after treatment $(7.52 \pm 5.57)$ was significantly lower than that in the control group $(10.74 \pm 4.75 ; \mathrm{P}<0.001)$ and ADL score in the observation group $(46.38 \pm 10.27)$ was significantly higher than that in the control group $(36.28 \pm 10.51 ; \mathrm{P}<0.001)$. Similar results were reported by $\mathrm{Xu}(24)$ and Lim et al (25). Control group was treated with conventional drugs, and combined use of $\mathrm{HBO}$ was performed in the treatment group and better efficacy was achieved. HBO is an ideal treatment for postoperative rehabilitation of brain tumor patients. HBO reduces flow of cerebral arteries in patients with brain tumors, so symptoms of hypoxia were improved. At the same time, HBO can also improve the ability of the body to sterilize and engulf necrotic cells, so as to achieve the elimination of lesions (26). Without timely treatment, brain cells around the tumor 'ischemic penumbra area' will die and patients' life and health will be endangered.

In conclusion, conventional therapy plus $\mathrm{HBO}$ is more effective than conventional therapy alone in postoperative rehabilitation of brain tumors. It can improve the inflammatory response of brain tumor patients, reduce the flow rate of cerebral arteries, and effectively reduce the number of patients with cerebral arterial spasm. At the same time, it lowers NFD and improves ADL. Therefore, it should be popularized in clinical practices.

\section{Acknowledgements}

Not applicable.

\section{Funding}

No funding was received.

\section{Availability of data and materials}

The datasets used and/or analyzed during the present study are available from the corresponding author on reasonable request.

\section{Authors' contributions}

SH drafted the manuscript. SH and GW were mainly devoted to collecting and interpreting the general data. JL and $\mathrm{HC}$ performed ELISA. SH and CC interpreted cranial color Doppler ultrasonography result. All authors read and approved the final study.

\section{Ethics approval and consent to participate}

The study was approved by the Ethics Committee of People's Hospital of Rizhao (Rizhao, China). Signed informed consents were obtained from the patients or the guardians.

\section{Consent for publication}

Not applicable.

\section{Competing interests}

The authors declare that they have no competing interests.

\section{References}

1. Sonoda J and Wharton RP: Drosophila Brain Tumor is a translational repressor. Genes Dev 15: 762-773, 2001.

2. Calabrese C, Poppleton H, Kocak M, Hogg TL, Fuller C, Hamner B, Oh EY, Gaber MW, Finklestein D, Allen M, et al: A perivascular niche for brain tumor stem cells. Cancer Cell 11: 69-82, 2007.

3. Winkler F, Kozin SV, Tong RT, Chae SS, Booth MF, Garkavtsev I, Xu L, Hicklin DJ, Fukumura D, di Tomaso E, et al: Kinetics of vascular normalization by VEGFR2 blockade governs brain tumor response to radiation: Role of oxygenation, angiopoietin-1, and matrix metalloproteinases. Cancer Cell 6: 553-563, 2004.

4. Amariglio N, Hirshberg A, Scheithauer BW, Cohen Y, Loewenthal R, Trakhtenbrot L, Paz N, Koren-Michowitz M, Waldman D, Leider-Trejo L, et al: Donor-derived brain tumor following neural stem cell transplantation in an ataxia telangiectasia patient. PLoS Med 6: e1000029, 2009.

5. Kircher MF, de la Zerda A, Jokerst JV, Zavaleta CL, Kempen PJ, Mittra E, Pitter K, Huang R, Campos C, Habte F, et al: A brain tumor molecular imaging strategy using a new triple-modality MRI-photoacoustic-Raman nanoparticle. Nat Med 18: 829-834, 2012.

6. Bondy ML, Scheurer ME, Malmer B, Barnholtz-Sloan JS, Davis FG, Il'yasova D, Kruchko C, McCarthy BJ, Rajaraman P, Schwartzbaum JA, et al; Brain Tumor Epidemiology Consortium: Brain tumor epidemiology: Consensus from the Brain Tumor Epidemiology Consortium. Cancer 113 (Suppl): 1953-1968, 2008.

7. Sadetzki S, Chetrit A, Freedman L, Stovall M, Modan B and Novikov I: Long-term follow-up for brain tumor development after childhood exposure to ionizing radiation for tinea capitis. Radiat Res 163: 424-432, 2005.

8. Marois P: Hyperbaric oxygen treatment. Ann Neurol 74: 149, 2013.

9. Ogawa K, Yoshii Y, Inoue O, Toita T, Saito A, Kakinohana Y, Adachi G, Iraha S, Tamaki W, Sugimoto K, et al: Phase II trial of radiotherapy after hyperbaric oxygenation with chemotherapy for high-grade gliomas. Br J Cancer 95: 862-868, 2006.

10. Luna-Oliva L, Ortiz-Gutiérrez RM, Cano-de la Cuerda R, Piédrola RM, Alguacil-Diego IM, Sánchez-Camarero C and Martínez Culebras Mdel C: Kinect Xbox 360 as a therapeutic modality for children with cerebral palsy in a school environment: A preliminary study. NeuroRehabilitation 33: 513-521, 2013.

11. McIntyre S, Taitz D, Keogh J, Goldsmith S, Badawi N and Blair E: A systematic review of risk factors for cerebral palsy in children born at term in developed countries. Dev Med Child Neurol 55: 499-508, 2013.

12. Nordberg A, Miniscalco C, Lohmander A and Himmelmann K: Speech problems affect more than one in two children with cerebral palsy: Swedish population-based study. Acta Paediatr 102: 161-166, 2013

13. Fan X, Mikolaenko I, Elhassan I, Ni X, Wang Y, Ball D, Brat DJ, Perry A and Eberhart CG: Notch1 and notch2 have opposite effects on embryonal brain tumor growth. Cancer Res 64: 7787-7793, 2004

14. Schneweis S, Grond M, Staub F, Brinker G, Neveling M, Dohmen C, Graf R, Heiss WD and Shuaib A: Predictive value of neurochemical monitoring in large middle cerebral artery infarction. Stroke 32: 1863-1867, 2001

15. Zhao YP, Zhang YQ, Duan HY, Ma Y, Liang H, Zhang QH, Xue CQ, Luo B and Pan X: Intracranial mixed germ cell tumor. Zhonghua Yi Xue Za Zhi 97: 661-665, 2017 (In Chinese).

16. Tian L, Lin Q and Zhang J: To explore the community rehabilitation assessment scales for patients with stroke sequelae. Glob J Cardiovasc Cerebrovasc Dis 3: 16-20, 2015.

17. Kranke P, Bennett M, Roeckl-Wiedmann I and Debus S: Hyperbaric oxygen therapy for chronic wounds. Cochrane Database Syst Rev 14: CD004123, 2004.

18. Bennett MH, Feldmeier J, Hampson N, Smee R and Milross C: Hyperbaric oxygen therapy for late radiation tissue injury. Cochrane Database Syst Rev 5: CD005005, 2005.

19. Thom SR: Hyperbaric-oxygen therapy for acute carbon monoxide poisoning. N Engl J Med 347: 1105-1106, 2002.

20. Yin W, Badr AE, Mychaskiw G and Zhang JH: Down regulation of COX-2 is involved in hyperbaric oxygen treatment in a rat transient focal cerebral ischemia model. Brain Res 926: 165-171, 2002 . 
21. Palzur E, Vlodavsky E, Mulla H, Arieli R, Feinsod M and Soustiel JF: Hyperbaric oxygen therapy for reduction of secondary brain damage in head injury: An animal model of brain contusion. J Neurotrauma 21: 41-48, 2004.

22. Chen LF, Tian YF, Lin CH, Huang LY, Niu KC and Lin MT: Repetitive hyperbaric oxygen therapy provides better effects on brain inflammation and oxidative damage in rats with focal cerebral ischemia. J Formos Med Assoc 113: 620-628, 2014.

23. Schellart NA, Reits D, van der Kleij AJ and Stalpers LJ: Hyperbaric oxygen treatment improved neurophysiologic performance in brain tumor patients after neurosurgery and radiotherapy: A preliminary report. Cancer 117: 3434-3444, 2011.

24. Xu WZ: Clinical effect of hyperbaric oxygen therapy in patients with brain tumor and cerebral aneurysm. Chin J Practical Nervous Diseases 20: 61-62, 2017.
25. Lim SW, Wang CC, Wang YH, Chio CC, Niu KC and Kuo JR: Microglial activation induced by traumatic brain injury is suppressed by postinjury treatment with hyperbaric oxygen therapy. J Surg Res 184: 1076-1084, 2013.

26. Lin L: Effectiveness of postoperative hyperbaric oxygen interventional therapy for patients with brain tumor and cerebral aneurysm. Chin J General Practice 11: 684-685, 2013.

(i) $(9$ This work is licensed under a Creative Commons Attribution-NonCommercial-NoDerivatives 4.0 International (CC BY-NC-ND 4.0) License. 